Rizzo, L. (2013). Shades of empire: Police photography in German South-West Africa. Visual Anthropology: Published in cooperation with the Commission on Visual Anthropology,

\title{
Shades of empire: Police photography in German South-West Africa
}

\author{
Lorena Rizzo
}

\begin{abstract}
This article looks at a photographic album produced by the German police in colonial Namibia just before World War I. Late 19th- and early 20th-century police photography has often been interpreted as a form of visual production that epitomized power and regimes of surveillance imposed by the state apparatuses on the poor, the criminal and the Other. On the other hand police and prison institutions became favored sites where photography could be put at the service of the emergent sciences of the human body-physiognomy, anthropometry and anthropology. While the conjuncture of institutionalized colonial state power and the production of scientific knowledge remain important for this Namibian case study, the article explores a slightly different set of questions. Echoing recent scholarship on visuality and materiality the photographic album is treated as an archival object and visual narrative that was at the same time constituted by and constitutive of material and discursive practices within early 2oth-century police and prison institutions in the German colony. By shifting attention away from image content and visual codification alone toward the question of visual practice the article traces the ways in which the photo album, with its ambivalent, unstable and uncontained narrative, became historically active and meaningful. Therein the photographs were less informed by an abstract theory of anthropological and racial classification but rather entrenched with historically contingent processes of colonial state constitution, socioeconomic and racial stratification, and the institutional integration of photography as a medium and a technology into colonial policing. The photo album provides a textured sense of how fragmented and contested these processes remained throughout the German colonial period, but also how photography could offer a means of transcending the limits and frailties brought by the realities on the ground.
\end{abstract}

\section{Police photography as discursive practice}

Time and again police photography captivates the social imaginary. Images of surveillance seem to provide a tangible sense of what Jean and John Comaroff [2004] have referred to as the metaphysics of disorder, the intense preoccupation with crime and, concurrently, the state's means of restoring public order and society's ability to explain the roots and causes of social deviance. The past decades saw innumerable mug-shots and photos of crime scenes escaping the closure and secrecy of barred filing cabinets at police stations and entering a variety of new discursive spaces-among them the internet, the museum 
and the gallery, thus serving a desire to catch a glimpse of the uncanny, unknown and scary. Exhibitions, accompanied by richly illustrated and high-value catalogs, have served a growing spectacle of mischief and misdeed [Carney 2010], causing though a discursive disjuncture by which police photography has been increasingly blended into a problematic aesthetic of exposure, violence and death. ${ }^{1}$ Enabled by the release to the public of photos from the collections of large police departments in Europe, the United States and Australia, the narratives developed within the exhibition space have largely drawn from a modernist argument that underscores the role of photography in the emergence of modern forms of policing and the constitution of state apparatuses of surveillance in late 19th- and early 2oth-century metropolitan contexts. ${ }^{2}$ A substantial body of scholarship also followed this metropolitan thread, and Allan Sekula's seminal essay, "The Body and the Archive" [1988], set sustainable parameters for a discussion that emphasized the predominance of realist and objectifying modes of vision in the 19th century and photography's link to the instrumental power of the state [Edwards 2001: 11]. In line with and echoing the notion of the Foucauldian panopticon, police photographs were hence interpreted as signature images for disciplinary practices, embodying the scopic regimes that mirrored the control, surveillance and classification of the poor, the criminal, the social and cultural Other [Lalvani 1990; Maxwell 2010: 49 ff.; Rajchman 1988; Regener 1999; Tagg 1988: 61 ff.].3

The problem of "othering" in particular has enabled this literature to resonate into the scholarship concerned with the imperial proliferation of photographic technologies and the place of photography in colonial systems of classification and taxonomy. Elizabeth Edward's work has been constitutive at this point, highlighting the discursive interfaces between photographs of surveillance and the visualization of anthropological types [Edwards 1990, 1997, 2001; Maxwell 2010: $10 \mathrm{ff}$.]. Edwards and others have accounted for the conjunction of 19th-century photographic and scientific naturalism and the importance of photography's claim to render anthropological material objectively. A substantial part of anthropological-and more so anthropometric-photography of the time was firmly grounded in and helped consolidate physiognomic theories that conceived of the human body in terms of a physical bearer of culture and race [Edwards 1990, 1997; Evans 2002; Pinney 2011; Roberts 1997]. For example, Edwards' discussion of T. H. Huxley's monumental project of recording the peoples of the British Empire, with its beginnings in mid-19th-century colonial India, rendered sophisticated accounts of the enabling of anthropometric photography in those spaces where power, policing and surveillance by the colonial state were most coercive-in prisons [Edwards 1997; Green 1984].

Obviously colonial institutions of policing and imprisonment constituted sites of repression, isolation and, in many instances, brute violence. But we need to remain cautious in anticipating the relationship between the reality of policing and the forms of visual production within these spaces [Pick 1989; Pinney 2008: 61 ff.]. 4 Photographs, even those produced by the police, remain fragmented, uncontained and ambiguous in their capacity to acquire different meanings through space and time, and as I will try to show, they might modify the grand narrative of surveillance, open new frames of reference and interrupt 
homogenizing views about police photography and the ways in which it can become historically meaningful [Edwards 2001: 3].

It is in this vein that the article approaches a specific set of photographic images produced in colonial Southern Africa early in the 20th century. This material raises specific methodological and theoretical problems, and the photographs' status as historical sources, to use a slightly old-fashioned term, 5 and representations of the past will remain critical throughout the analysis. Most of photography's history, and particularly in the late 19th and early 20th centuries, emerged from preoccupations with the medium's indexicality, i.e., the notion of its capacity to render the reality placed in front of the lens objectively. ${ }^{6}$ Methodologically photography's ontological realism, and by implication its truth-claims, enduringly favored concerns with image content and the question of what is depicted and what we see. Image content remains, as Edwards and Hart have argued, fundamental to any understanding of photographs [Edwards and Hart 2004: 2]. Yet I hope to show throughout the discussion of the Southern African material that the photograph's indexicality as such proves problematic in the first place and always implies an act of interpretation that complicates the image's quality at the level of historical meaning [Hughes and Noble 2003: 5; Tagg 1988: 3]. Shifting the focus away from image content alone, I will instead treat the photographs as images and objects, making sense first of all of the ways in which we encounter them in the colonial archives.7 Thinking with and of photographs as images and objects accounts for the fact that "they exist materially in the world, as chemical deposits on paper, as images mounted on a multitude of different sized, shaped, colored and decorated cards, as subject to additions to their surface or as drawing their meanings from presentational forms such as frames and albums" [Edwards and Hart 2004: 1]. The processes involved in the production, circulation and use of photographs make the notion of them being objects moving through time and space tangible [Banks and Vokes 2010: 339]. But paying attention to the photographs' materiality pushes analyses further toward questions of how they actively created and sustained social relations, generated meaning and became marked as specific objects through the practices attached to them [Edwards 2002; Edwards and Hart 2004: 3; Pinney and Peterson 2003: 3; Rose 2000].

\section{The album}

The first object that serves as a point of entry is an album 8 produced between about 1911 and 1915 by the German colonial administration in Namibia.9 It is lettered in German as "Fotografie Album 1b, Farbige"10 and kept in the characteristic blue cover, which anchors it within the chronologies of administrative archival practice. At first sight the album qualifies, materially and visually, as a so-called "rogues gallery" [Phillips et al. 1997], i.e., a genre that emerged in the late 19th century in the context of profound social concerns with crime in general and with recidivism in particular [Sekula 1988; Hamilton and Hargreaves 2001: 57 ff.; Jäger 2003]. Rogues galleries, as these albums were popularly called, assembled images of men and women, who had repeatedly been targeted by state authorities for a variety of offenses, such as theft, fraud, moral misbehavior, manslaughter or 
murder. As an object and assemblage of images the album constituted the ultimate product of a wide range of spatially and temporally dispersed photographic practices linked to processes of methodological, technological and professional reconfiguration of police and prison institutions [Jä ger 2001]. Indeed, these practices emerge throughout the album pages.

When I first looked at the album in the reading room of the National Archives of Namibia in 2010, I was impressed with the object's aura caused by its singular presence within the archives, ${ }^{11}$ the strong sense of the album's authenticity, its age made visible by traces of past careful handling, the fading color of the cover, and eventually by a strong sense of privileged vision within the institutional space of that archive itself. ${ }^{12}$ Measuring ca. $40 x$ $33 \mathrm{~cm}$, the album contains 40 pages, all of which have prefabricated incisions for mounting eight to twelve and occasionally more single photographs by their corners on each page. No author is given, no information on the photographer(s) who produced the images, nor is it clear if photography and album composition had been the work of one or several persons. When I browsed through it for the first time, one page after the other, I got a sense of purposeful fabrication-a visual narrative and graphic composition, systematized through almost two-thirds of the album, with each page regularly covered by images, yet increasingly coming apart toward the end. In fact, the back part of the album rather resembled a scrapbook with loose photographs randomly inserted between the pages, stitched to each other in image samples or carelessly glued somewhere. It is this material instability of the album as an entity that I'd like to investigate first.

\section{Figure 1}

This first image illustrates the graphic pattern of the album's substantial part. The page and the photo mount determine the composition of the photographs, meant to be lined up in varying numbers of rows. It presents the serial and uniform photographic depiction of individual men, some of whom appear to be kept in chains. The photographs suggest a formalized and compulsive photographic situation, in which men have been placed before a wall; full-length front and profile views alternate and repeat themselves. No constables are shown. The formalism and graphic determinism are meaningful here. Repetitiveness and formal similarity inevitably invoke a transcending movement, a larger body of images, all of which become comparable, serial and similar. A reference beyond the single album page is underway, inducing vision and contemplation to cast clouds into a shadow archive [Sekula 1988: 7]. But there is also a strong sense of within-a visual compression, a closing of ranks. The chains marking the men's status as captives almost unremarkably perforate the photographs' frames; one man chained to the next, one image to another. A space of confinement becomes visible, and a space of blunt vision is enforced-as if the panopticon would play itself out, again and again, from page to page throughout the album. ${ }^{13}$ 


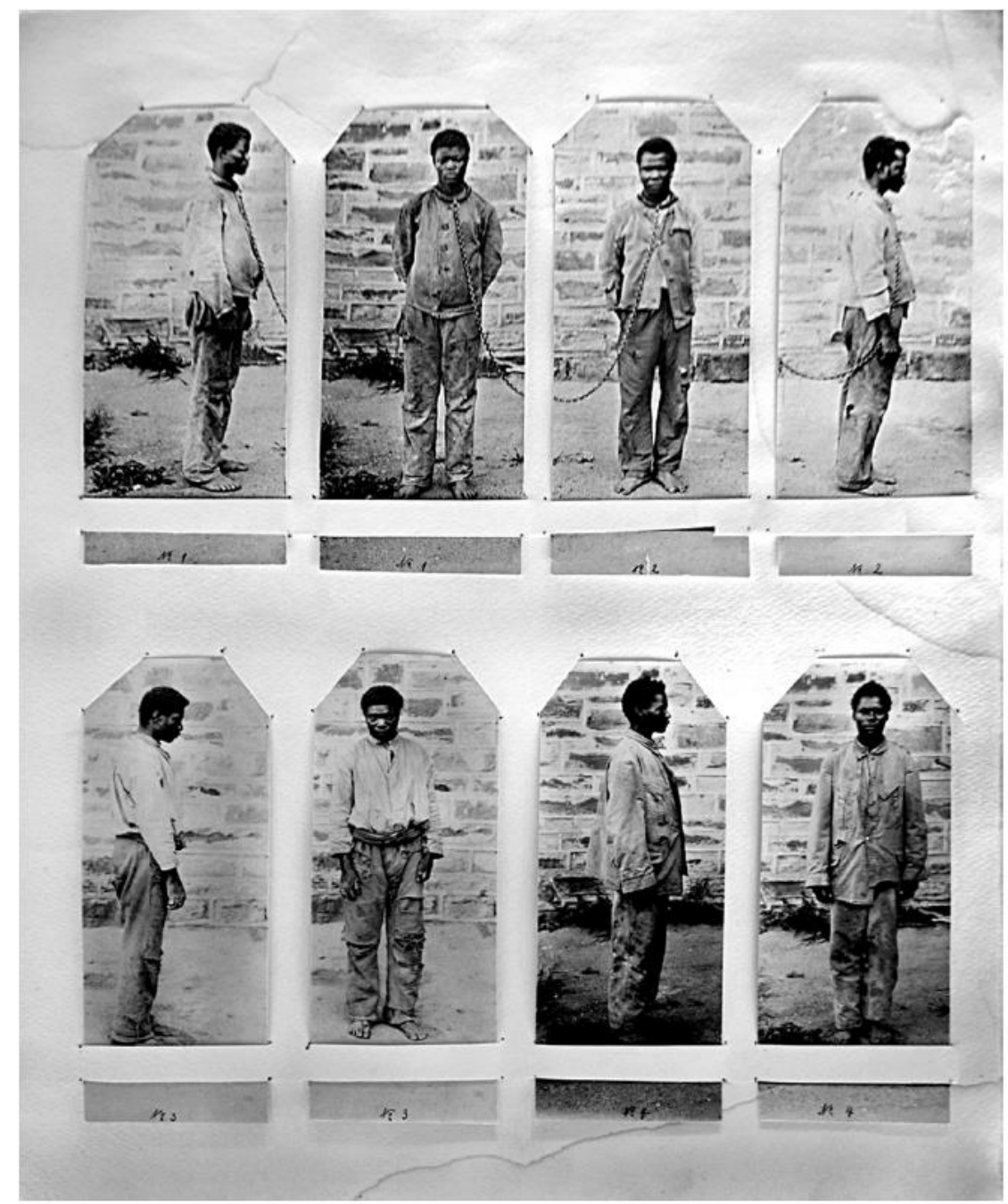

Figure 1 Photographer unknown: Fotografie Album 1b, Farbige. Windhoek, 1911-1914. (National Archives of Namibia, ZBU Pol/A. 737)

\section{Figure 2}

But there are, as suggested before, ruptures and interruptions. The page selected to illustrate here exemplifies inconsistent practices, shifting temporalities, chan- ging locations and fractured, unstable visualities. The photographs have been arranged unsystematically, there are differences in image quality and material condition. Loose images placed between the album pages, photos stapled together into image samples, and tattered images constitute residues of image production, circulation and use [Edwards 2002: 74]. Fragments of time and space, physical trajectories and narrative transformations pile up in random layers of images. This page is as much about visual overcrowding as it is about the congestion of time, and about their erratic entanglement. And an almost unnoticeable writing-a script-creeps in. Numbers, names, codes, identifiers that feature now and then, inconsistently, on the back of some photographs, alongside the image rows, in page corners, throughout the album, as almost tentative, discreet attempts at order and register, remaining nebulous at some points, and becoming more consistent at others. 


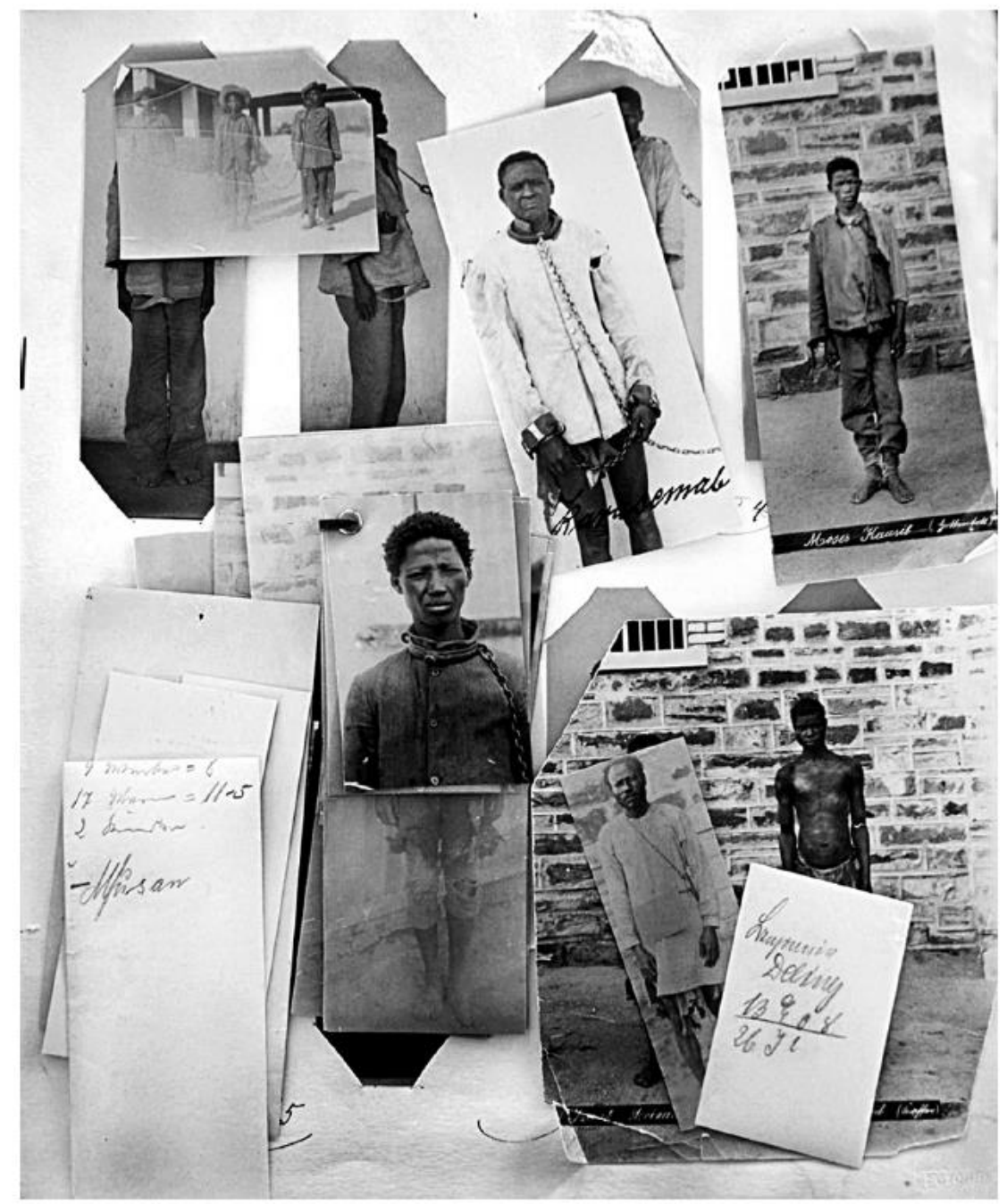

Figure 2 Photographer unknown: Fotografie Album 1b, Farbige. Windhoek, 1911-1914. (National Archives of Namibia, ZBU Pol/A. 737)

\section{Figure 3}

And finally there is a puzzle. At two points the album becomes ambitious, almost arrogant in the deployment of its visual idiom. These photographs appear on different album pages and there is an odd sense of misplacement, of coincidence or hazard at least. Here the men have been asked to place their hands on their chests, allowing for the staging of a visual code that became popular in metropolitan police and prison photography by the $1900 \mathrm{~s}$ [Tagg 1988: 87-88], but it rather seems to indicate in this context the graphic experiment of an individual policeman and=or photographer, possibly an archivist or collector, and less a well-established visual strategy of the album.

So what is this album about? What does its presence in the Namibian archives, its singularity, its status and nature as an object tell us? What does it mean? Do we encounter yet another example of the production of images of surveillance, peripheral colonial 
variations of the grand narrative of modern metropolitan policing, a petty economy of mug-shots? ${ }^{14}$

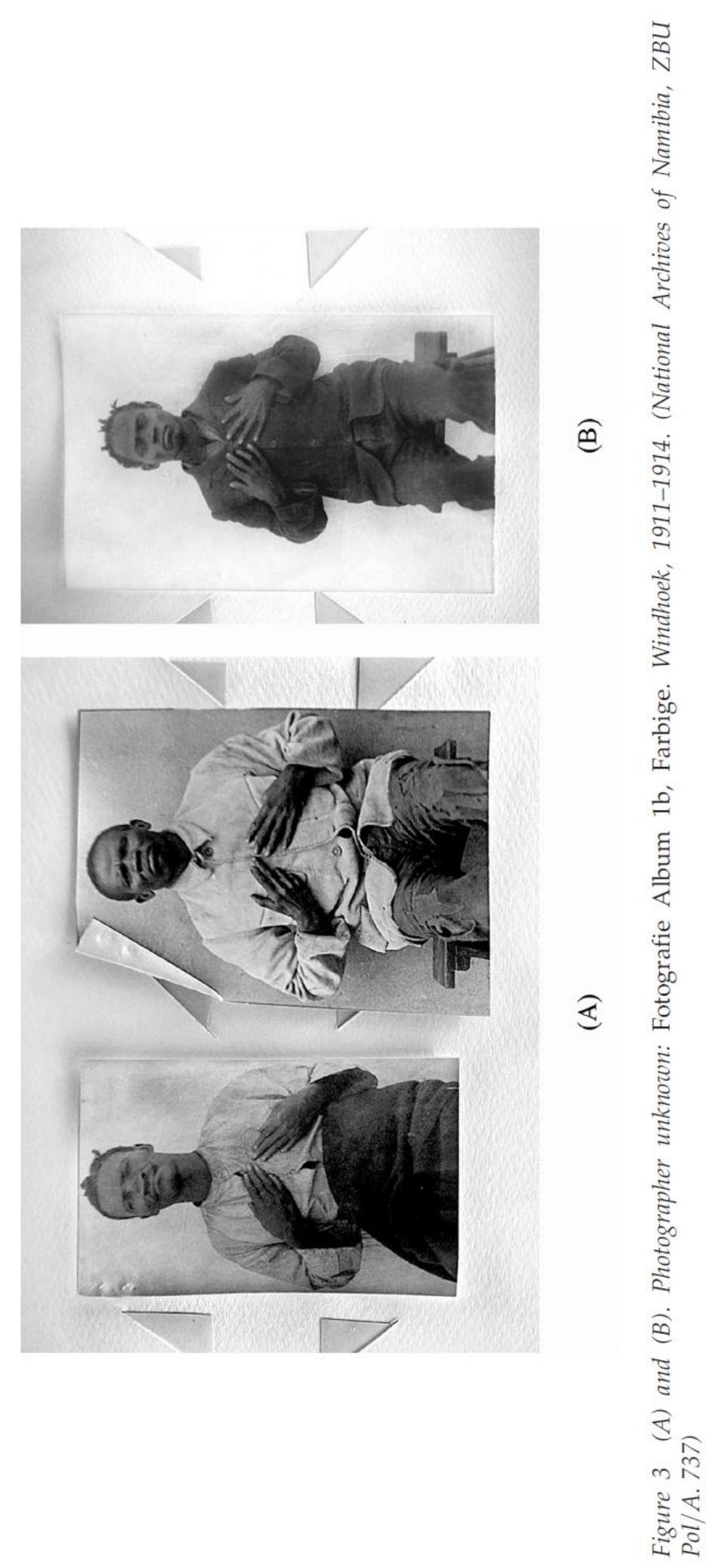


Or is this album an example of an amateurish photographic practice which would at best qualify as an awkward flirtation with Bertillon? ${ }^{15}$ It is, indeed, all of this, and much more.

\section{Practices}

The German police album is a miniature photographic archive, a site infused with power-to accumulate and collect, to see, to know, and so to narrate. ${ }^{16}$ It is an object embodying a range of relations and practices, "social modalities" that surround the images and inform the ways in which they have been produced, circulated, displayed and interpreted [Rose 2001, quoted in Schwartz 2004: 7]. The album's beginnings probably coincide with the establishment of the police records department by the German colonial administration in Windhoek in 1911. ${ }^{17}$ There had been preliminary rumor and anxiety in 1906. Governor von Lindequist had then bemoaned the intrusion of what he called "criminal gangs" from the Cape (to the south), who profited from the chaotic conditions caused by the war ravaging German South-West Africa at the time. It seemed, von Lindequist suggested, as if these "gangs" were expanding their activities throughout Namibia and were up to serious mischief in and around the coastal town of Swakopmund. ${ }^{18}$ The Governor suggested to close ranks and to entice the Cape government to provide the authorities in Windhoek with photographs of and personal information on the brigands, whom he supposed to have entered police records as a matter of course. In exchange von Lindequist generously offered to cede photographs taken of detainees in the German colony to the Cape police forces. The utopian vision of mutual support through modern technology was thwarted, though, by the German consul-general in Cape Town, who recalled earlier German attempts to get hold of the storied "rogues gallery" in the possession of the Cape prison authorities, and opted for diplomatic tactfulness and ad hoc ways of cooperation once the government in Windhoek would get hold of the culprits. ${ }^{19}$ Von Lindequist's initiative stranded, presumably drowned by the immediacy and urgency of an ongoing war, and eventually materialized as an archival singularity, an unintentional narrative disjuncture.

The archive suggests new momentum from 1911 onwards. Yet information remains fractured. Scattered documents and single photographs do not provide a clear picture. Hence rather than forcing these fragments into a uniform narrative of visual surveillance, let alone into a linear chronology of the establishment of photographic technology in the colonial bureaucracy, I will try to develop an argument in terms of the institutional practices and power relations through which the album, the single photographs and the written archival record become historically meaningful. There is a problem of scale and of the point in time, as if the album and the few images and documents gravitating around it refuse to be blended into the visual dispositive of the colonial war in Namibia, 1904-1907, and its spectacle of the prisoner-of-war camps [Langbehn 2010; Olusoga and Erichsen 2010]. These archival fragments did not emerge from violent escalation, short term destruction and immediate death; there's no closure here. On the contrary, these fragments invite us to pay attention less to the exceptional and more to the ordinary, less

\section{http://repository.uwc.ac.za}


to the singular event and more to the repetitive and the everyday. ${ }^{20}$ The concerns and practices that became constitutive for the production of a "rogues gallery" in the aftermath of the colonial war in Namibia resulted from the German authorities' intent to inaugurate a situation of naturalized and routinized rule over the territory, once the war had brutally broken African resistance and had seemingly sorted things out for good [Zimmerer 2001: 125]. ${ }^{21}$ This shift toward an everyday routine articulated itself within the police bureaucracy through growing interest in professionalization and modernization. ${ }^{22}$ At this point we can explore some of the practices around the photographs and the German police album and sketch how observation, photographic production, reproduction and display evolved. There was space for practical experimentation and a theoretical ambition to position oneself in the forefront of modern criminalistics, modeled along the metropolitan police departments in Berlin and Hamburg

\section{Figure 4}

In late February 1912 the central government in Windhoek issued a directive that circulated widely within the German colonial bureaucracy. It meticulously elaborated the various methods the police should henceforth apply and the kind of record to be produced on persons who had been arrested. The methods included dactyloscopy or fingerprinting, on the one hand, and Bertillonage, i.e., a standardized anthropometric description combined with a portrait photograph and a portrait parlé, i.e., a spoken portrait, on the other. ${ }^{24}$ The parallel use of different methods was not unusual. Although fingerprinting outplayed Bertillonage in criminal identification in the 1890 s, some features and practices subsumed under the term Bertillonage continued to exist, in the metropole as much as in the empire [Kaluzinski 2001]. The question was not one of method alone but rather one of reference and classification, as any information generated, written or visual, required an analogous record in a register or archive. It was this archive with its filing systems and classification which had most importantly been provided by Bertillon. 25 For the purpose of this article it will be enough to establish the productive vigor of the methodological me'lange exercised by the German colonial police, resulting in a complex compendium of material objects and images. There is however an important absence in the archives and the material preconditions of production, the technologies and infrastructures involved, their sites and spaces, remain nebulous, often unclear. Things necessarily appear distorted, disproportionate, and there is a danger of overstating the archival remains. The corpus of discrete images and abstract visualizations-the photos, the physiognomic drawings of eyes, noses, ears, heads and faces, and the blackened papillary ridges carefully inserted into standardized forms-as fractured as they might be- appeal to the senses and powerfully incite to assume an archive of identifiable and verifiable individualities. I'm suggesting a kind of optical illusion or phantasmagoria of the archive, with its own productive forces and its potential for self-delusion ${ }^{26}$ 


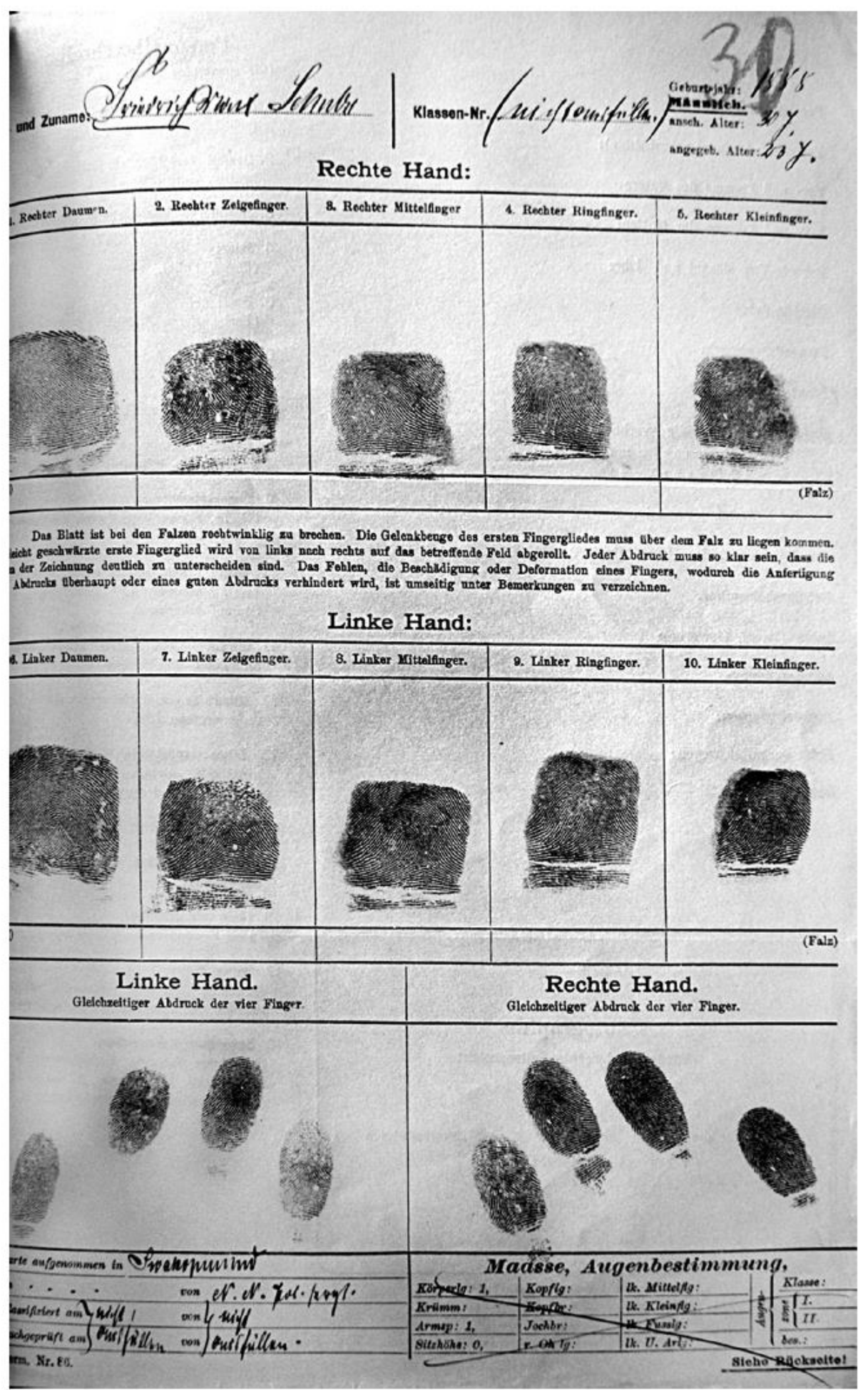

Figure 4 Dactyloskopy. Kaiserliches Gouvernement an das Kaiserliche Bezirksamt Windhoei February 29, 1912. (National Archives of Namibia, ZBU 752 G II a 4) 
The enthusiasm among theoreticians within the German colonial police had its pragmatic counter-characters, though. The articulation and application of fingerprinting and Bertillonage on the ground provoked debate within the administrative bodies. In late April 1912 the magistrate in Windhoek drew a picture of general confusion within the bureaucracy. ${ }^{27}$ There was apparently no consensus on which detainees and convicts had to be subjected to anthropometric description and portraiture. Generally the officer remained very critical of the applicability and aptitude of the cumbersome procedures in the colony [Pinney 2008: $61 \mathrm{ff}$.].

In contrast to the German motherland, he argued, in South-West Africa there was no centralization of the departments of criminalistics and, more importantly, the general conditions were characterized by dispersal and vastness on the one hand and tight social control on the other hand:

Yet, in the colony the disappearance of the individual in the masses, who would merely be traceable thanks to registered personal data, is impossible. With ease any person recorded may disappear either entirely and will remain untraceable due to the terrain, or he will move into inhabited settlements, and there he can be recognized shortly without any kind of personal record, as the narrow settings per se facilitate knowing and recognizing [sic!] others. ${ }^{28}$

Flimsiness in the practice and practicability of criminal identification emerged moreover from material and institutional shortcomings, and suspicion of bureaucratic complacency sneaked in. ${ }^{29}$ While the magistrates in the coastal towns of Swakopmund and Lü deritzbucht had apparently established a continuous practice of delivering fingerprints, descriptions of persons and photographs of "white" and "black" offenders to the central government, none of the others provided any information at all, or at most very irregularly. Windhoek insisted though that, once all regional offices and police bodies were equipped with cameras, photography would play a crucial role in identification that would in most cases suffice to establish an individual's identity. ${ }^{30}$ Indeed the authorities claimed that the chronicles of successful prosecution of "black criminals, cattle thieves, burglars, and vagrants" thanks to photographs (sic!) were remarkable and that in some cases the images had also allowed for the arrest of "white" offenders. ${ }^{31}$ Some of the trajectories of the photos and the fingerprints emerge from the archive. To their discomfort, the colonial authorities eventually faced the problem of transforming the visual data they were accumulating into something useful. One way of doing so was to explore the broader advantages of fingerprinting for colonial government. In 1912, for example, fingerprinting proliferated into a variety of social practices, 32 thus symbolically enforcing the notion of the individual uniqueness of the fingertip and the implicitness of colonial modernization. Usurpation and manipulation of pass-discs by colonial subjects and the dissatisfaction with "native crosses" used as signatures on documents and treaties [Zimmerer 2001: $125 \mathrm{ff}$.]

\section{http://repository.uwc.ac.za}


offered indeed a wide field of application and expanded fingerprints' ambit far beyond the shallows of the filing cabinet. 33 But there is more to be said about the photographs here.

\section{Figure 5}

This image shows a search warrant to which a photograph of a man in a convict uniform has been stitched. 34 The man was kept on a chain and forced to wear a number plate around his neck. It is indeed as if the bureaucratic practices of the police had literally been inscribed onto his body, thereby transforming the individual into an object of rule, numbered, classified and inserted into a system of criminal identification: embodied power was inscribed and made visible. 35 The warrant and the photo were sent from the prison in Windhoek to the police in Rehoboth, and copied to the offices of the police and court in the colonial capital. 


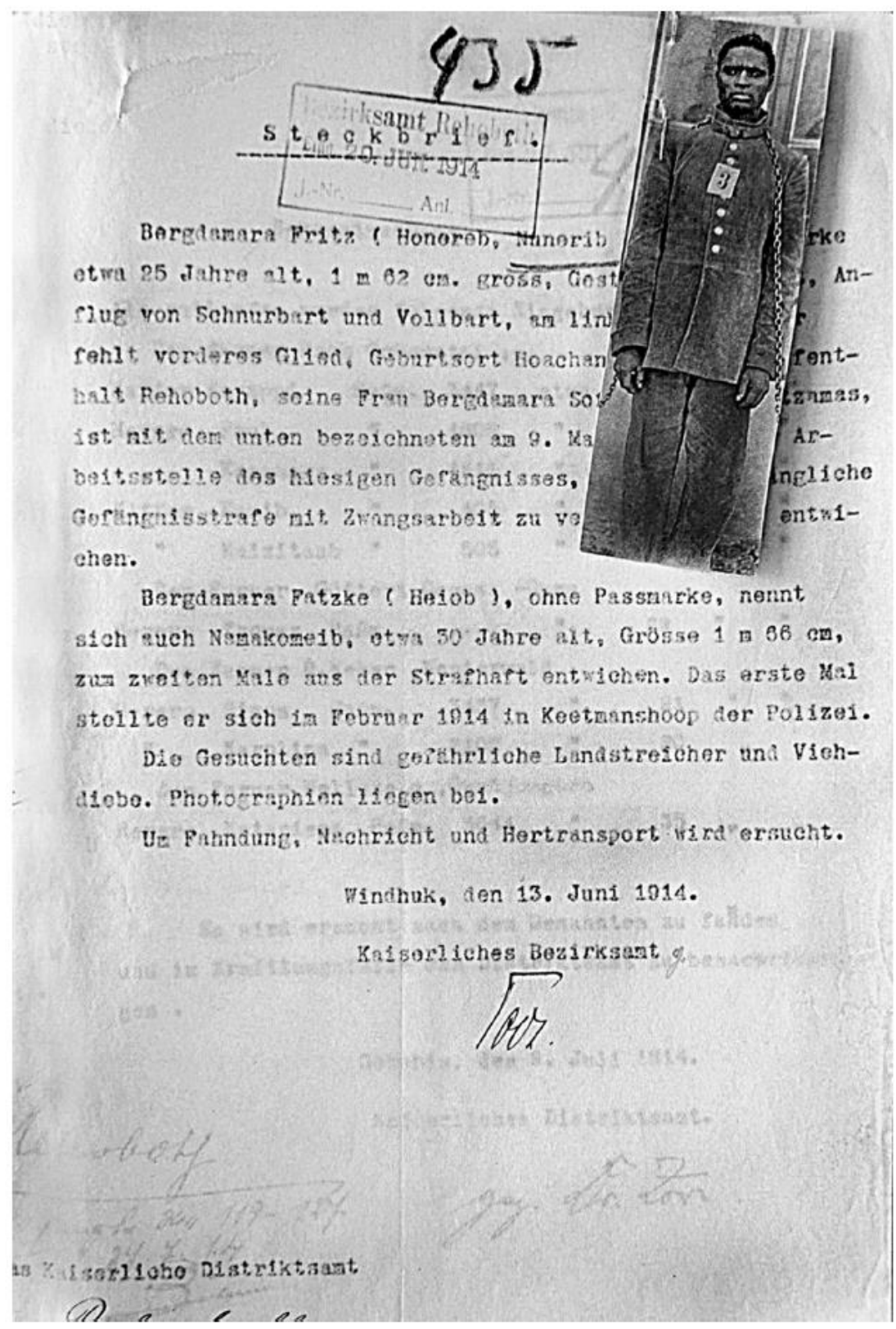

Figure 5 Photographer unknown: Search Warrant. Bezirksamt Windhoek an das Bezirksamt Rehoboth, June 13, 1914. (National Archives of Namibia, BRE 27)

We do not know if this is one of the cases in which a fugitive could be traced and identified "thanks to a photograph." What becomes visible here instead is how the portraits and mug shots of criminalized individuals became a bureaucratic technology and vehicle for institutional integration..$^{36}$ The reproduction and serial distribution of the image within the colonial bureaucracy multiplied the act of submission visible in the photograph, as much as it marked the formal chains of the state apparatus and nurtured processes of selfascertainment within the colonial administration [Jä ger 2003: 208-210; Ignatieff 1981: 177]. 
However, I would like to broach a slightly different reading. If we have a closer look at this photo as part of a warrant there is space to re-complicate the question of time and temporalities. Photographs slice out one particular moment and freeze it [Sontag 1979: 15], and it is precisely this slicing which perpetuates the condition of captivity. The replication pushes validity forward beyond time and space, turning the frame into a contingent space of never-ending subjugation. But there's a slippage: the warrant is, in fact, about two men (one of the photos went missing at some point) and it is its material presence reminding us that the two men, Otto Kaimub and Fritz Honoreb, were on the run. This is the strongest tension of the warrant as a genre and the level on which the conversation with the photograph destabilizes and troubles space and time. While the image alone suggests confinement, what emerges here are indeed loopholes and escape ways, bandit itineraries rather than single acts of crime, and spaces beyond prosecution and the penitentiary system. But there's also an element of integration between the warrant and the image which produced meaning as the photo is reintroduced into multiple narratives. One of these narratives, though it remains rudimentary, concerns the lives of the criminalized men. We read about Kaimub's and Honoreb's offenses (they moved around without passes, of all things), register the results of their anthropometric description, and learn about their place of origin and the harshness of their life sentences and imprisonment with forced labor in Windhoek. But the narrative most insistently imposed is one on colonial governance and the individual's relationship with the state, mediated through the language of colonial law [J. L. Comaroff 1998]. It is this narrative which condensed in such peculiar but powerful ways in the practice of a manhunt.

The materiality of warrants in the archive is eclectic. Sophisticated publications by police institutions in Berlin, London, Cape Town or Johannesburg contrast their procedure with the simplicity of the German colonial Fahndungsblatt produced between 1908 and 1910.37 Difference is most notable with regard to the use of photographs, which abound in the former and remain consistently absent in the latter. This might be explained by the decentralized character and relative weakness of the visual economies of policing in the German colony before 1911. 38 More remarkable though is the exclusive consideration of "white" offenders in the Fahndungsblatt, which was less due to an implicit articulation of racism than grounded in a specific correlation between "whiteness" and social visibility made by the colonial authorities in South-West Africa at the time. Yet the instance of a particular case troubles the alleged unambiguousness of this interpretation.

\section{Figure 6}

This image shows a side view of two men, Friedel Falk und Bruno Sommer, convicted as culprits in a frightening case of multiple murders in 1912 [Budack 1999]. The photograph has its equivalents in a set of front views and focused portraits that form part of a body of documentation on the clarification of the case, and the activities of the policemen involved in finding the outcasts, who had been on the run in the area around Windhoek for weeks. This case is of particular interest because it came to constitute one of the model events around which the colonial police force applied its entire repertoire of forensic investigation. In line

\section{http://repository.uwc.ac.za}


with the methodological credo of criminalistics the two men, once the police got hold of them, were subjected to thorough questioning, to meticulous physiognomic description, fingerprinting and forensic photography. 40 The density and coherence of photographic practices is indeed remarkable, as they also included forensic photographs of the main victim's dead body, ${ }^{41}$ sectional photos of the crime scenes, and photographs of objects relevant to the case. ${ }^{42}$

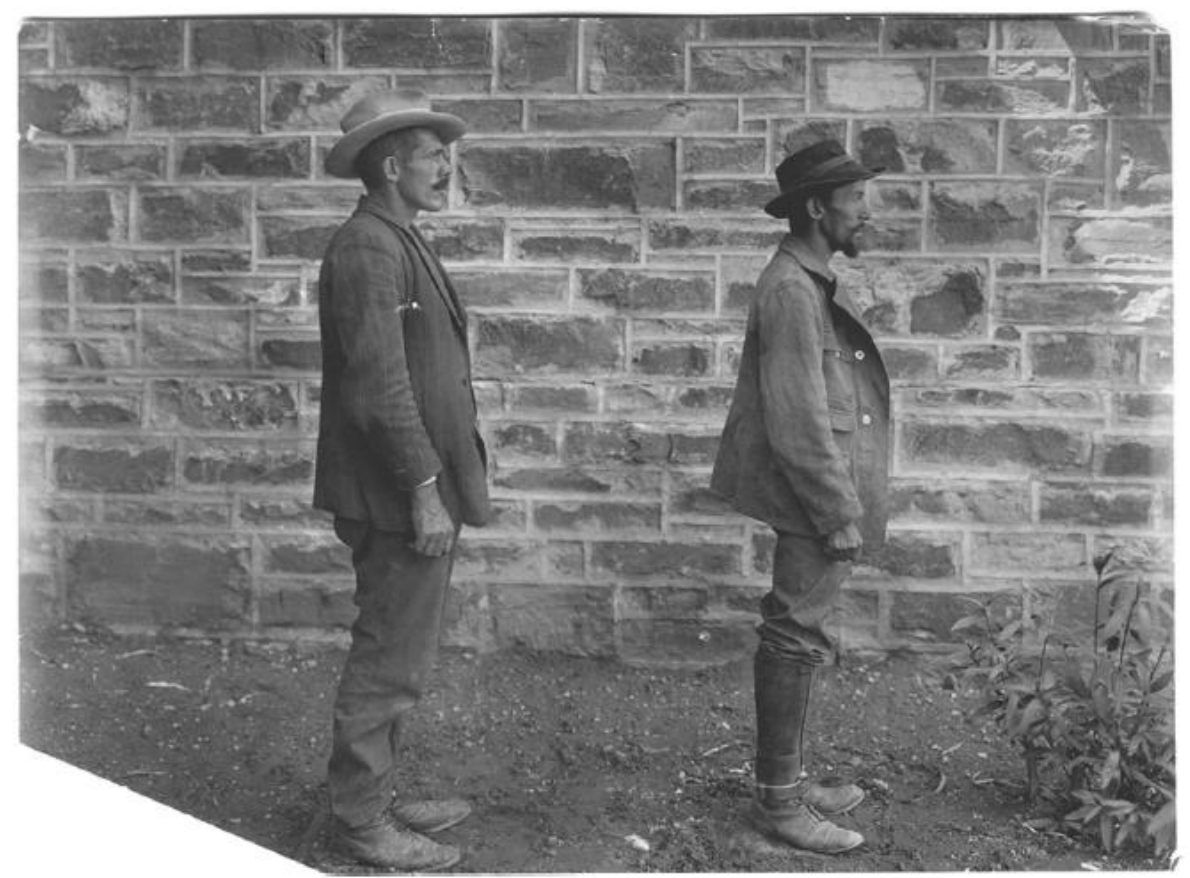

Figure 6 Photographer unknown: Friedel Falk and Bruno Sommer in the prison yard, 1912. (National Archives of Namibia. Bezirksamt Windhoek, K 10/12 Bd. IV, Akten über Strafsache Falk und Sommer)

In the course of the investigation, when the police were concerned with gathering evidence for the events of the crimes and for the detainees' involvement, the photos of Falk and Sommer taken in prison were displayed at a number of public sites, such as the local newspaper's main office and the library in Windhoek. Directions for their use and the public's involvement were clear:

Naturally, the duty to support the authorities to throw light on the crime accrues from the community. This mustn't lead to conditions now prevailing in some of the big cities at home, where one or the other believes himself to be a second Sherlock Holmes, and practices the art of detectives on his own account. Instead each and everyone is requested to share all his knowledge about incidents, which might be relevant for the investigation, with the authorities. [.. .] Photographs of Sommer and of Falk will be displayed in our [the newspaper's] main office and in the library. 43 
Reading through the records on the case and the narrative framed around Falk and Sommer, both of whom were eventually sentenced to death [Budack 1999: $233 \mathrm{ff}$.], it seems as if the German colonial authorities discursively coined the whole case almost as a sociopathological exception and naturalized the death sentences in terms of an inevitable closure. Simultaneously, the institutional handling of the investigation was celebrated as a success of modern criminalistics in the colony. 44

\section{The "native" subject}

Against the backdrop of the investigative practices emerging around the genre of the search warrant and the specific forensic verve maturing around the Falk and Sommer case, the contours of the archival singularity of the album begin to show.

But let me explore its privileged place within the visual economy of policing first by material absence, namely Album 1a. Because the "rogues gallery" as a genre constituted a practice and narrative that transcended the immediacy of ad hoc police work, it became a space in which racial segregation could be articulated more consistently than within the constriction and narrowness of actual police stations and prisons operated in the territory at the time. 45 Hence, the album related to Farbige, i.e., "blacks," and labeled as $1 b$, was most probably coupled sequentially with a precedent album on "whites" or European perpetrators, now missing in the archives. ${ }^{46}$ The absence embodied in the reference to a series of albums creates a silence of a specific kind [Trouillot 1997: 48], and we'll have to keep this silence in mind while having a closer look at Album $1 b$.

As an object and set of photos the album inherently allowed for a conceptual and narrative selection, arrangement and display of a circumscribed number of photographs. The strategic nature of practice, the contemplation in the process of composition, and the care with which the album had to be envisaged was consciously articulated within the German colonial police bureaucracy. It became a privileged site of intervention reserved to the central government. Launched as a photographic project in the context of the establishment of the Erkennungsdienst in 1911, the administration of the album was determined from its very beginning:

For the rogues gallery (Verbrecheralbum) the administrative offices will only send in photographs of persons who've either been previously convicted or who have proved to be part of the world of professional criminality through their current felonies. The inclusion of the photograph in the album is decided upon by the government. 47

Alongside the album a certain degree of classification $a^{`}$ la Bertillon was applied, which resulted in a register of prisoners. 48 The rubrics included numbers referring to further administrative registers, names and "nation" (i.e., tribal category), passdisc number, crime, sentence, employer, enforcement of sentence, and the date of discharge. The register provides an uncanny narrative on the criminalization of Africans in Namibia under German 
colonial rule; it tells the stories of men prosecuted for theft, fraud, vagrancy, alcoholism, assault or desertion of their employers and punished with draconian sentences ranging from flogging to hard labor or several years of imprisonment. 49 While the list includes roughly 50 individuals the correlation with the album remains interrupted. Indeed, just a few photos from the album unequivocally fit the information in the register, a disjuncture linked to the ways in which the colonial administration framed the constitution of the album. In most cases after all, the selection of the photos and their weaving into the confined narrative of the album obscured earlier archival conjunctions.

This archival interruption, disjuncture and eclipsing reinforces the homogenizing gesture of the album as a visual narrative. The ways in which it displays the photographs indeed emphasize repetitiveness, annihilates singularity and privileges the optical inventory rather than the subjects of the photos. $5^{0}$ Still, what we actually encounter in the German album is a spatial configuration in which it is precisely the constitution of the subject, though in idiosyncratic ways, taking shape.

There is a discursive dialectic of visibility and invisibility at play. The German album is about criminals, detainees, convicts, in short people who have been locked away behind the stone walls of the colony's prisons, in the seclusion and darkness of peripheral police posts, confined to muggy and dirty cells. They have been removed, hence, beyond the lens of colonial society, out of the field of vision of those who simultaneously emerge as law-abiding citizens. It is the criminals' occlusion which clears the ground for what Michel Foucault has described as the deployment of technologies of the visual in spaces of constructed visibility. ${ }^{1}$

\section{Figure 7}

Hence another page that points to the blunt voyeurism of knowledge that frames the album's narrative. This peculiar visualization seemed to satisfy a desire to "know the criminal" by seeing him, over and over again. The album almost seemed to offer unlimited and uninhibited peepholes to the privileged gaze screening the subordinate human landscape of social deviation and alterity: crime made flesh [Pierce and Rao 2006]. The album as a specific object and visual narrative within the visual practices of the police was less about image content, about what or whom the German colonial authorities and at times even larger publics (remember von Lindequist's vision of image exchange) would see. 


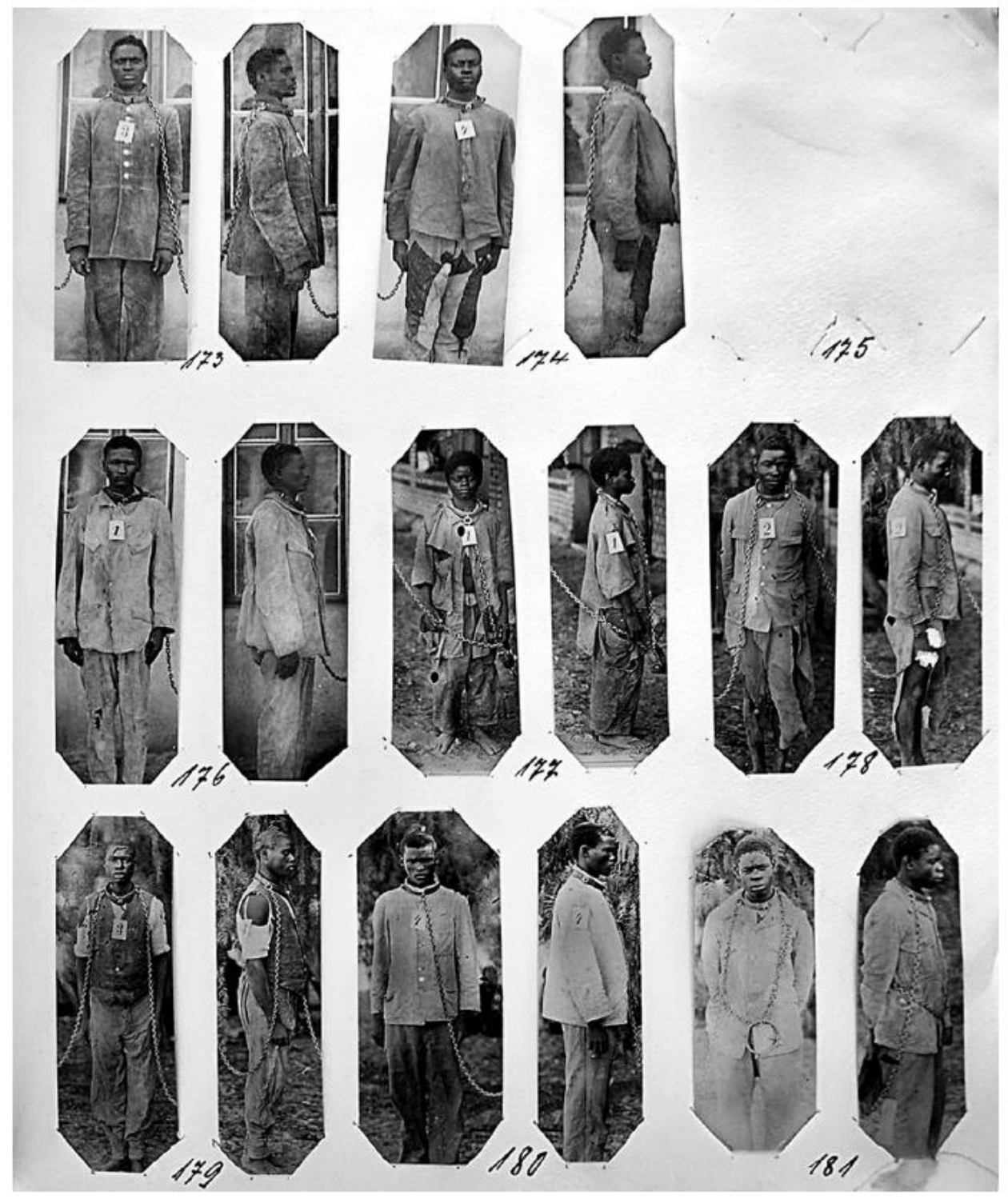

Figure 7 Photographer unknown: Fotografie Album 1b, Farbige. Windhoek, 1911-1914. (National Archives of Namibia, ZBU Pol/A. 737)

It was much more about how the subjects of the photographs were made visible, and how power was visualized through the institutional practices of the police [Lalvani 1990: 87]. And there is no space for multi-vocalism or visual versatility. The "native subject" is confined to an embodiment of crime, of potential violence and moral corruption. $5^{2}$ After all, the absence of Album 1a, of a similar exposure of "whites," was perhaps less a matter of archival loss than one of colonial power hesitating. Police photography as it appeared in the album was ultimately about the constitution of race, both "black" and "white," and the visual inscription of racial difference within the framework of legal, moral and social integrity and respectability. In the early 1910 s though, the conditions in the German colony were, as the case of Falk and Sommer and the recurrence of diverse forms of banditry show, by far settled in the colonial authorities' minds.

\section{http://repository.uwc.ac.za}


Though I have so far argued for an understanding of the album as a discursive entity, an archive which frames the ways in which the photos of criminalized subjects become meaningful, it is the album itself which entices one to pause with one particular set of photographs, troubling the inner logics of the narrative in notable ways.

\section{Figure 8}

These are the only two photographs of a woman in the album and their presence forecloses any hasty assumption about criminal visual recording under German colonial rule. The production of police and prison photos affected men and women in fundamentally different ways. While women had been exposed to the camera during the war of 1904-1907 as prisoners in camps [Hartmann 2004: $32 \mathrm{ff}$.], the institutionalized and routinized visual documentation and registration in police stations and prisons in the early 1910 s seem to have predominantly focused on male prisoners. 53 It is against the backdrop of this almost total visual absence of female convicts that these two photographs suggest a narrative and interpretational backpedaling. There is an intense congestion and complication of meaning here, caused by the fracture and contestation of certainties and well-defined teleologies of colonial state formation and its penal institutions 54 and the constitution of colonized subjects. One of these certainties concerns the structural marginalization of African women in the realm of the law 55 and their relegation to a set of offenses organized within the framework of a moral economy of the body. These offenses coalesced in a discursive insistence on female transgressions of morality that became legally epitomized as prostitution. ${ }^{56}$ On the other hand, the biased economic rationale of colonial criminalization and imprisonment targeted mainly men as subjects of forced labor to be used on settler farms, in mines or on infrastructural construction sites [Wallace 2011: $183 \mathrm{ff}$.]. The grand narratives of colonial rule hence impose an understanding of the woman's appearance in the album as an instance to be merely explained either by randomness or contingency in the album's composition, 57 or in terms of an irreducibly individual deviance of this particular subject. Thereby the photographic seclusion of the woman in the album emerges as a sortie-from the visual as much as the political. 


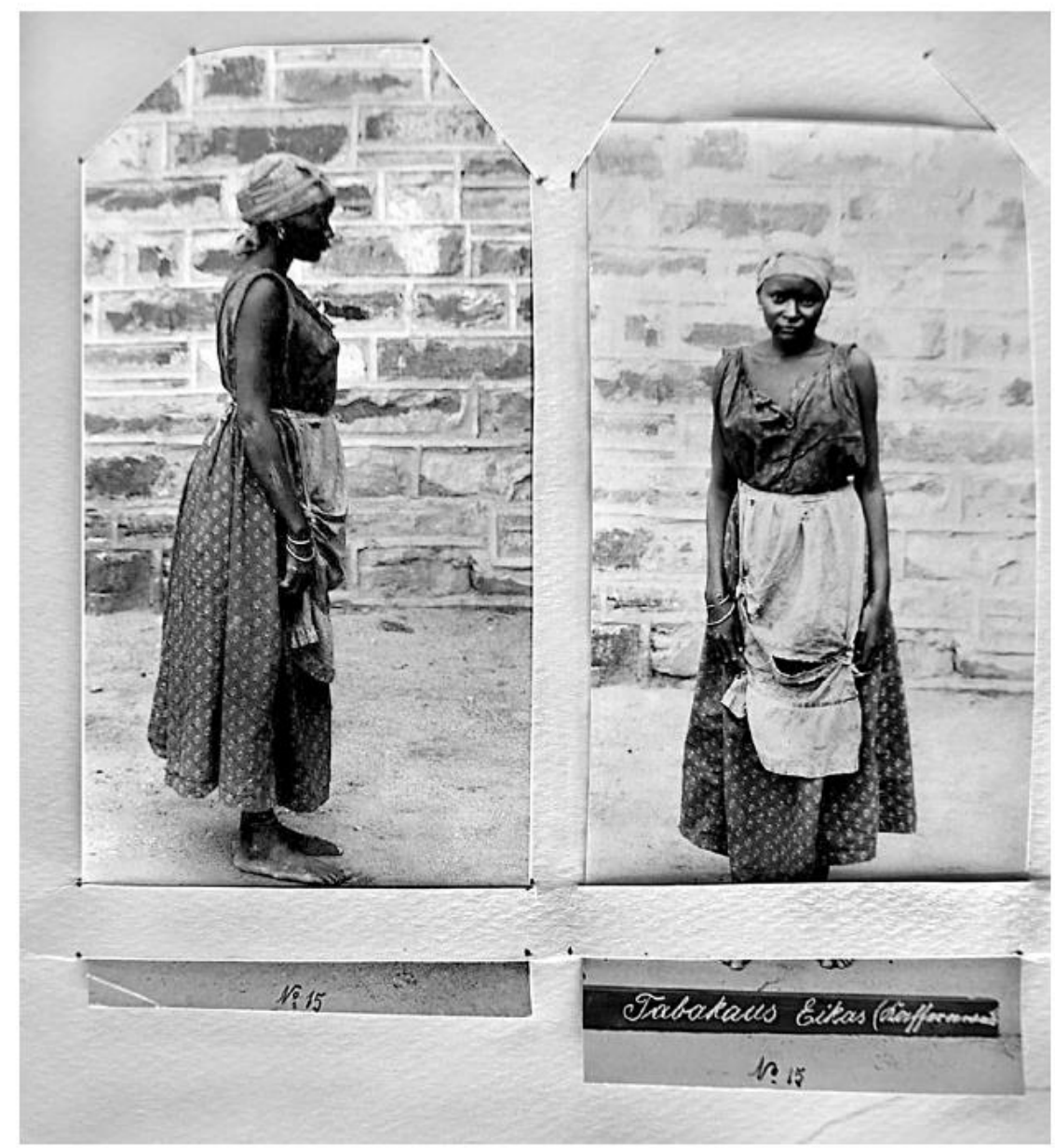

Figure 8 Photographer unknown: Fotografie Album 1b, Farbige. Windhoek, 1911-1914. (National Archives of Namibia, ZBU Pol/A. 737)

Still, the presence of the photographs and the visibility of the woman's subjection to criminal registration (apparent in the numbering and the black bar with her name on it) 58 clearly anchor them in the archive and signify, here as much as for all photos in the album, the effect of an archive of criminal classification that in the first place enables these photos to exist. On these grounds, the two images of the woman become a powerful reminder of a colonial visual tautology, a modernist gesture, which discursively prioritized race against gender, and articulated an abyssal claim to set the terms of vision and exposure.

\section{In conclusion}

Colonial prisons and police institutions have offered privileged sites for the production of anthropometric and anthropological photographs, where the submission of colonized subjects to the coercive power of the state could translate into visual codes of scientific disciplines concerned with the inscription of social, cultural and racial difference on the human body. ${ }^{60}$ This argument is very suggestive in assuming, at times implicitly, that "total institutions" such as prisons generate a specific kind of photography which more than anything embodies a repressive mode of vision and aims at the visual inscription of the 
criminal and Other. ${ }^{61}$ The reflections on the police album from colonial Namibia have necessarily echoed these theoretical positions. The men and one woman subjected to the visual exposure had been criminalized, prosecuted and detained under very precarious conditions, and the photos do remind us of routinized forms of violence endured by many subjects under colonialism. Sure enough, the draconian sentences imposed on Africans by the German colonial administration in the early 1910s served, in many instances, the logics of the political economy of forced labor rather than being in accordance with the requirements of the law. ${ }^{62}$ Ideologically the political repression, economic exploitation and regular incarceration drew much of their legitimization from hardened notions of racial inferiority of those forced into colonial tutelage [Wallace 2011: $183 \mathrm{ff}$.]. But the article has likewise tried not to categorize the photographs in terms of racial science and state surveillance prematurely. As said before, we do not know enough about the photographers and the authorship of the album, and the question of what these images were supposed to do 63 -in and beyond the context of policing-proved complicated. Thinking with the photos kept in the album, I have hence been interested in a circumscribed set of questions, among them, how we encounter photographs in the colonial archives, how their materiality speaks to their visuality, and how they have historically been organized into particular narratives. By exploring practices linked to a set of photos the article has sketched some of the ways in which these images became active and meaningful in specific institutional spaces and ideological formations in early 20th-century Namibia. My interpretation has shown that while the photos might have referenced anthropological and physiognomic imagery they were in the first instance administrative and marked the relationship between the state, its institutions of surveillance, and the criminalized subjects. The consolidation of German colonial rule in Namibia after the war of 1904-1907 and processes of professionalization within the colonial police were constitutive for the photographs considered here. But my approach has been less interested in a teleological history of the visual, which accounts for the introduction and anchorage of photography in colonial policing as an act of modernity. Rather the article has pursued more submerged and erratic histories made by visuals. 64 The result of such reading has been the complication of time and space induced by the album and its photos, and it has helped shed light on profound narrative ambiguity: on the one hand, the polythetic nature of the photographic medium concealed some of the fault-lines of colonial policing, ${ }^{65}$ and the discussion of the search warrant as a genre and practice addressed some of the tensions between the strategic visualization of captivity and the references to subaltern leeway lodged in the photos themselves. As much as the German colonial album remains an assemblage of captive images [Biber 2007], I hope to have shown throughout this article how the photos transcend the limits of categorical frames. Because photography enables us to catch close-up views of space and time, the selected photographs from colonial Namibia precisely invite us to grasp what eludes the broader narrative of criminalization, persecution and captivity in the colony. 


\section{Acknowledgments}

Earlier versions of this article have been presented in a public lecture at the History of Art Department, University of Michigan, and in the South African Contemporary History and Humanities Seminar, Centre for Humanities Research and History Department, University of the Western Cape. I would like to thank Giorgio Miescher, Dag Henrichsen, Anne Hermann, Leslie Witz, Stephen Miescher, Carola Schlettwein and Nina Sywamus for their critical comments.

\section{Notes}

1. Examples of such exhibitions and publications are Phillips, Haworth-Booth and Squiers [1997]; Rugoff, Widler and Wollen [1997]; Wride and Ellroy [2004]; Phillips [2010]. For a more general theoretical discussion on photography moving from one discursive space to another, see Krauss [1982].

2. This also applies for Campbell [2009], who looks at European women in colonial Sydney exclusively, without considering indigenous ones. For the sake of readability I am not discussing the appropriation of police photos in art and popular culture as part of an imaginary of crime here, though it does play an important part in most exhibitions mentioned.

3. Important nuances to this argument are in Jä ger [2001].

4. Hamilton and Hargreaves [2001] are less sophisticated in this regard.

5. Peter Burke [2001]: his argument is firmly grounded in a framework of social and cultural history, but remains helpful for methodological problems precisely on the question of photos as source-material used by historians.

6. See the numerous texts in Trachtenberg [1980], or Kelsey and Stimson [2008: xiii].

7. Obviously my approach owes much to Elizabeth Edwards's work; e.g., Edwards [2001].

8. All photographs discussed in this article were taken by myself in the National Archives of Namibia in August 2010.

9. National Archives of Namibia (NAN) ZBU Pol=A. 737.

10.In English, "Photographic Album 1b, Blacks." It is somewhat unusual that the term Farbige (blacks) is used instead of Eingeborene (Natives), which was much more common at the time.

11.The term "aura" is commonly linked to Walter Benjamin's work, and often referred to as a mere aesthetic category. My use of the term echoes Benjamin's more complex understanding of aura as a way of theorizing the conditions of possible experience linked to the presence of an object (of art). For an elaborate discussion, see Bratu Hansen [2008].

12.I was introduced to the album by the head archivist, Werner Hillebrecht, who found it as soon as I had spoken about my interest in police photography in Southern Africa.

13.Panopticon is used here according to Foucault's discussion [1995] of the architecture of power.

14.Mug-shots usually show a person's front and profile view of the face or the head; e.g., Doyle [2005]. The use of the term "mug" for faces is linked to the representation of faces on drinking mugs popular in England since the mid-18th century. They were also 
known as Toby jugs, or more correctly Toby Fillpots (or Philpots). They take the form of a stout old man with a tricorn hat, the corners of which act as spouts. In the early 19th century there were similar Nelson jugs and Wellington jugs. Since these items were associated with popular underclass culture, by the early 19th century "mugging" acquired the double connotation of drinking and stealing [Tamony 1971].

15.Alphonse Bertillon developed the first modern system of criminal identification in Paris in 1879-80; Sekula [1988: 17]. I'll come back to this system later on.

16.Sekula's argument remains formative here; Sekula [1988], also Bate [2007].

17.This institution was called Erkennungsdienst in German. See NAN BWI 254, Kaiserliches Gouvernement von Deutsch Südwest Afrika an das kaiserliche Bezirksamt Windhuk, Windhuk, 3.8.1911.

18.NAN ZBU 751 G II a 4, Verbrecheralbum, Fingerabdrücke, Bd 1, Kaiserliches Bezirksgericht Swakopmund, von Lindequist an das kaiserliche Konsulat in Kapstadt, February 10, 1906. On colonial anxieties over flourishing criminal activities in Swakopmund in particular

19.and in southern Africa more generally, see Van Onselen [2007: 267-303], concerning

20.Swakopmund and Windhoek in 1905-6. How far von Lindequist had in mind the "criminal gangs" van Onselen talks about remains unclear. See also Zimmerer [2001: 149-150].

21.NAN ZBU 751, G II a 4, Verbrecheralbum, Fingerabdrücke, Bd 1, General-Konsul Kapstadt an den kaiserlichen Gouverneur von Lindequist, June 5, 1906. Apparently the Ethnographic Museum in Berlin had earlier on raised the same desire to be supplied with copies of the "rogues gallery" in Cape Town, and had got a negative response, allegedly because the Cape authorities considered the wider circulation of the photos as an "infringement of the feelings of those natives, who have been photographed." On efforts to acquire ethnographic and anthropometric collections in Germany in the late 19th and early 2oth centuries, see Krautwurst [2002].

22.On the significance of repetitiveness and seriality for the notion of the everyday, see Roberts [1997: 41].

23.Important in this regard is the institutional transformation resulting in the establishment of the Landespolizei. For a brief but accessible contemporary account of the Herero War, see Cana [1910: 802-803]. For a short ethnographic account of the Herero, see Vivelo 1995.

24.For a discussion of these processes of professionalization and modernization in the European metropole, see Jä ger [2003].

25.NAN BWI 254 Sicherheitspolizei und Erkennungsdienst. Erkennungsdienst Berlin, n.d. The files include various publications and regulations concerning the police departments in Berlin and Hamburg.

26.NAN ZBU 752 G II a 4, Verbrecheralbum und Fingerabdrücke. Das Kaiserliche Gouvernement an das kaiserliche Bezirksamt Windhuk, February 29, 1912. As is widely known, fingerprinting has its own imperial histories and emerged as a method of identification in colonial India in the later 19th century. See Cole [2002], in particular chapter 3; on Bertillonage, see Sekula [1988: 17].

27.Sekula's discussion of these processes is still among the most sophisticated [Sekula 1988]; also Cole [2002: 63]. 
28.On phantasmagoria, its original reference to optical illusion and its epistemic transformation, including the connection with the alienating power of imagination, see Castle [1988: 61]. He refers adequately to photography as the ultimate "ghostproducing" technology of the 19th century.

29.NAN ZBU 752 G II a 4, Verbrecheralbum und Fingerabdrücke. 23 März 1912, Kaiserlicher Bezirksamtmann Windhoek an das kaiserliche Gouvernement, Windhuk, March 23, 1912.

30.Same as in note 27; my translation.

31.NAN ZBU 752 G II a 4, Verbrecheralbum und Fingerabdrücke. Kaiserliches Bezirksamt Windhoek an das kaiserliche Gouvernement, Windhuk, July 22, 1913.

32.NAN ZBU 752 G II a 4, Verbrecheralbum und Fingerabdrücke. 23 März 1912, Kaiserlicher Bezirksamtmann Windhoek an das kaiserliche Gouvernement, Windhuk, March 23, 1912.

33.Same as in note 30. The unidentified officer made reference to portraits, photos of crime scenes and of objects related to crimes. This corresponds to Bertillon's categorization of the different types of criminal photography.

34.NAN BWI 254-Sicherheitspolizei und Erkennungsdienst. Kaiserliches Gouvernement an das kaiserliche Bezirksamt Windhuk, June 26, 1912. The Windhoek authorities explicitly modeled the wider social use of fingerprinting on experiences in the Cape Colony and the neighboring Portuguese territories.

35.The social proliferation of various forms of fingerprints is an integral part of its history 36.[Cole 2002: 60].

37.NAN BRE 27, Bezirksamt Windhuk an das Bezirksamt Rehoboth, Steckbrief, June 13, 1914.

38.On the standardization of the search warrant, see P. Becker [2001].

39.Michel Foucault's work has been fundamental in addressing the individual's entry into the field of knowledge production, and how the body has become a site of power; Foucault [1995]; Anderson [2004].

40.A similar argument has been made, following Max Weber, with regard to written documents as technologies of bureaucracy [Hull 2003].

41.Filed in NAN ZBU $751 \mathrm{G}$ II A 3, Fahndungsblätter. Fahndungsblatt is best translated as Police Gazette, though it literally means "manhunt publication."

42.I use the concept of visual economies in line with Poole [1997: 8].

43.Filed in NAN GWI 730 Bezirksgericht Windhuk K. 1O=12 Bd. IV, Akten über die Strafsache Falk und Sommer.

44.NAN GWI 730 Bezirksgericht Windhuk K. 1O=12 Bd. IV, Akten über die Strafsache Falk und

45.Sommer.

46.The photographs are published in Budack [1999]. Sergeant Hermann Strunck was considered to be the main victim in the case. Further victims, among them two children, were all Africans and identified by their pass-discs or by relatives questioned by the police.

47.NAN GWI 730 Bezirksgericht Windhuk K. 1O=12 Bd. IV, Akten über die Strafsache Falk und 
48.Sommer.

49.Südwestbote, April 5, 1912. Quoted in Budack [1999: 10], author's translation.

50.The narrative of the sources remains unquestioned in Budack's account [1999].

51.As far as I can tell at this stage, the implementation of racial segregation and separation according to gender in the big prisons, e.g., in Windhoek and Swakopmund, seems to have been a gradual process, which materialized in the construction of "modern" prisons for "native" and "white" men in Swakopmund in 1908. The prison for "white" men had 27 cells, of which 24 were designed for single prisoners while 3 were meant to host several men at a time. The capacity of the prison was hence limited to 32 inmates, but was at the time qualified as an enormous improvement over previous conditions. One of the main reasons to build the new prisons was that convicts sentenced to longer imprisonment could be kept in the colony (instead of being sent to Germany) and used for forced labor. The situation in smaller prisons and cells adjacent to police stations all over the territory most probably continued to be significantly different, where segregation of detainees remained impossible. See, e.g., NAN BSW 29, Gefängnissachen.

52.Werner Hillebrecht, head archivist of the National Archives of Namibia, who showed me Album 16 , was unable to locate further albums there.

53.NAN BWI 254 Sicherheitspolizei und Erkennungsdienst. Kaiserlicher Gouverneur von DSWA, Theodor Seitz, an das kaiserliche Bezirksamt Windhuk, Windhuk, August 3, 1911; my translation.

54.NAN BWI 254 G.8.q. Kaiserliches Bezirksamt Windhuk, Akten betreffend Sicherheitspolizei und Erkennungsdienst, Bd. 1, January 1, 1911, Verzeichnis der im Gefängnis befindlichen Gefangenen, n.d.

55.For a discussion of the socioeconomic reasons framing the criminalization of Africans in the brief German colonial period, see Wallace [2011: 183 ff.]. On the economic rationale of colonial confinement more generally, see Alexander and Anderson [2008]; for Africa, see Bernault [2007: 60].

56.I make this argument on the basis of Kracauer's discussion of photography, though his analytical emphasis is slightly different; Kracauer [1993: 431]. Thanks to Gary Minkley for referring to his argument during the "Developing the Common" Conference at the CHR of the University of the Western Cape, October 6-7, 2011.

57.For an elaborate discussion of the place of the visual in Michel Foucault's work, see 58.Rajchman [1988].

59.The entrenchment of crime, race and photography is a prominent topic in histories of photography; e.g., Biber [2007]; Bernault [2007: 64].

60.This is a preliminary statement. My sense of the archives suggests the "absence" of women in prison and police photography was grounded as much in the fragilities of police photography at the time as it was linked to the ideological construction of African male criminality.

61.For a critical discussion on teleological models of the emergence of modern penitentiary systems in Europe and the United States in the early 19th century, see Ignatieff [1981: $163 \mathrm{ff}$.$] .$

62.Discussed in more depth in Rizzo [2010: $194 \mathrm{ff}$.$] .$ 
63.Gendered differentiation in the prosecution of criminal offenders was significant in the late 19th and early 20th centuries and it reflected itself in photographic representation. Examples from Australia are discussed in Doyle [2005]. For a more general discussion on criminalized women and their visual recording in late 19th-century Western Europe, see Regener [1999]. On histories of African female criminality, see Zimudzi [2004: 500].

64.Here again, there is an important difference between the album as a visual narrative and the actual organization of prisons in German South-West Africa, which at the time had already introduced segregation of detainees according to gender, though the implementation in everyday detention practices remains unclear. Segregation of gender could imply African women's incarceration in prisons for "white" men. See two examples recorded in NAN BWI 254 G.8.q., Verzeichnis der im Gefängnis befindlichen Gefangenen, n.d.

65.The black bar, with the subject's name on it, is a recurrent visual marker in the album. In some of the photos it is clear that the bar was actually placed on the ground in front of the person and the photographic frame adapted to include it, in order to create the illusion of a visual rather than a material device.

66.I'm far from assuming the German colonial police and penitentiary system to have been a functionally efficient "total institution" in terms of Goffman's model; far from that. The more so, I would argue, police photos and the album in particular became a representational space in which colonial authorities strove for the comprehensiveness and coherence which they lacked on the ground. As such, the album articulated a tautology within a modernist notion of the order of vision as a whole; Haxthausen [2004: 55]. On Goffman, see H. S. Becker [2003].

67.Besides the relevant literature mentioned in the introduction to this article, scholars of Southern Africa have likewise looked at anthropological and anthropometric photography produced in prison institutions; e.g., Webster [2000]; Bank [2006].

68.For a general critique of the argument see Jä ger [2001].

69.For the broader legal argument, see Rizzo [2007], and for the economic context Bley [1968: 26off].

70.My phrasing loosely echoes W.J.T. Mitchell's critique of equating desire and power when it comes to the investigation of what images do [Mitchell 1996: 74].

71.The phrasing goes back to Christopher Pinney and is referred to in the introduction to Hayes [2006: 2].

72.For the broader discussion that builds on Michel de Certeau's argument, see Edwards [2001: 132].

73.Edwards [2001: 3], based on Carlo Ginzburg's argument in support of the microhistorical method. 


\section{References}

Alexander, Jocelyn, and Clare Anderson 2008 Politics, Penalty and (Post)Colonialism. Introduction to a special issue on Prison and the Political. Cultural and Social History, 5(4): 391-394.

Anderson, Clare 2004 Legible Bodies. Race, Criminality and Colonialism in South Asia. Oxford and New York: Berg.

Bank, Andrew 2006 Photographs and Body Marks: Breakwater Prison, January to September 1871. In his Bushmen in a Victorian World. The Remarkable Story of the Bleek-Lloyd Collection of Bushmen Folklore. Pp. 102-127. Cape Town: Double Storey.

Banks, Marcus, and Richard Vokes 2010 Introduction: Anthropology, Photography and the Archive. History and Anthropology, 21(4): 337-349.

Bate, David 2007 The Archeology of Photography: Reading Michel Foucault and the Archeology of Knowledge. Afterimage, 35(3): 3-4.

Becker, Howard S. 2003 The Politics of Presentation: Goffman and Total Institutions. Symbolic Interaction, 26(4): 659-669.

Becker, Peter 2001 The Standardization of the Search Warrant in 19th Century Germany. In Documenting Individual Identity. Jane Caplan and John Torpey, eds. Pp. 139163. Princeton and Oxford: Princeton University Press.

Bernault, Florence 2007 The Shadow of Rule: Colonial Power and Modern Punishment in Africa. In Cultures of Confinement. A History of the Prison in Africa, Asia and Latin America. Frank Dikö tter and Ian Brown, eds. Pp. 55-94. Ithaca, NY: Cornell University Press.

Biber, Katherine 2007 Captive Images. Race, Crime, Photography. Abingdon and New York: Routledge-Cavendish.

Bley, Helmut 1968 Kolonialherrschaft und Sozialstruktur in Deutsch-Südwestafrika 1894-1914. Hamburg: Leibniz.

Bratu Hansen, Miriam 2008 Benjamin's Aura. Critical Inquiry, 34: 335-375.

Budack, Kuno F. R. 1999 Raubmord 1912. Die 'Falkund Sommermorde.' Ein Beitrag zur Kriminalgeschichte von Deutsch-Südwestafrika. Windhoek: in-house publisher.

Burke, Peter 2001 Eyewitnessing. The Uses of Images as Historical Evidence. London and Ithaca, NY: Cornell University Press.

Campbell, Nerida 2009 Femme Fatale: The Female Criminal. Sydney: Historic Houses Trust of New South Wales.

Cana, Frank R. 1910 German South-West Africa. In Encyclopædia Britannica (11th edn.), 11: 800-804. Chicago: Encyclopædia Britannica Co.

Carney, Phil 2010 Crime, Punishment and the Force of Photographic Spectacle. In Framing Crime: Cultural Criminology and the Image. Keith Hayward and Mike Presdee, eds. Pp. 17-35. Abingdon and New York: Routledge.

Castle, Terry 1988 Phantasmagoria: Spectral Technology and the Metaphorics of Modern Reverie. Critical Inquiry, 15: 26-61.

Cole, Simon A. 2002 Suspect Identities. A History of Fingerprinting and Criminal Identification. Cambridge, MA, and London: Harvard University Press. 
Comaroff, Jean, and John L. Comaroff 2004 Criminal Obsessions, after Foucault: Postcoloniality, Policing, and the Metaphysics of Disorder. Critical Inquiry, 30(4): $800-824$.

Comaroff, John L. 1998 Reflections on the Colonial State in South Africa and Elsewhere: Factions, Fragments, Facts and Fictions. Social Identities, 4(3): 321-362.

Doyle, Peter 2005 Public Eye, Private Eye: Sydney Police Mugshots, 1912-30. SCAN Journal, 2(3). http:// www.scan.net.au

Edwards, Elizabeth 1990 The Image as Anthropological Document. Photographic Types: The Pursuit of a Method. Visual Anthropology, 3: 235-258.

1997 Ordering Others: Photography, Anthropologies and Taxonomies. In In Visible Light. Photography and Classification in Art, Science and the Everyday. Chrissie Iles and Russel Roberts, eds. Pp. 54-68. Oxford: Museum of Modern Art.

2001 Raw Histories. Photographs, Anthropology and Museums. Oxford and New York: Berg.

2002 Material Beings: Objecthood and Ethnographic Photographs. Visual Studies, 17(1): $67-75$.

Edwards, Elizabeth, and Janice Hart 2004 Introduction. Photographs as Objects. In Photographs Objects Histories. On the Materiality of Images. Elizabeth Edwards and Janice Hart, eds. Pp. 1-15. New York and Oxford: Routledge.

Evans, Andrew D. 2002 Capturing Race. Anthropology and Photography in German and Austrian Prisoner-of-war Camps during World War I. In Colonialist Photography: Imag(in)ing Race and Place. E. M. Hight and G. D. Sampson, eds. Pp. 226-256. London: Routledge.

Foucault, Michel 1995 Discipline and Punish: The Birth of the Prison. New York: Random House.

Green, David 1984 Veins of Resemblance: Photography and Eugenics. Art Journal, 7(2): 3-16.

Hamilton, Peter, and Roger Hargreaves 2001 The Beautiful and the Damned. The Creation of Identity in 19th Century Photography. London: National Portrait Gallery Publications.

Hartmann, Wolfram 2004 Hues between Black and White. Historical Photography from Colonial Namibia 186os to 1915. Windhoek: Out of Africa.

Haxthausen, Charles W. 2004 Reproduction=Repetition: Walter Benjamin=Carl Einstein. October, 107: 47-74.

Hayes, Patricia 2006 Visual Genders, Visual Histories. Malden and Oxford: Blackwell.

Hughes, Alex, and Andrea Noble 2003 Phototextualities. Intersections of Photography and Narrative. Albuquerque: University of New Mexico Press.

Hull, M. 2003 The File: Agency, Authority and Autobiography in an Islamabad Bureaucracy. Language and Communication, 23: 287-314.

Ignatieff, Michael 1981 State, Civil Society, and Total Institutions: A Critique of Recent Social Histories of Punishment. Crime and Justice, 3: 153-192.

Jäger, Jens 2001 Photography: a Means of Surveillance? Judicial Photography, 1850 to 1900. Crime, History and Societies, 5(1): 2-25. 
2003 Erkennungsdienstliche Behandlung. Zur Inszenierung polizeilicher Identifikationsmethoden um 1900. In Geschichtswissenschaft und performativer turn.' Ritual, Inszenierung und Performanz vom Mittelalter bis zur Neuzeit. Jü rgen Martschukat and Steffen Patzold, eds. Pp. 207-228. Köln: lag.

Kaluzinski, Martine 2001 Republican Identity: Bertillonage as Government Technique. In Documenting Individual Identity. Jane Kaplan and John Torpey, eds. Pp. 123-138. Princeton and Oxford: Princeton University Press.

Kelsey, Robin, and Blake Stimson 2008 The Meaning of Photography. New Haven and London: Yale University Press.

K racauer, Siegfried 1993 Photography. Critical Inquiry, 19(3): 421-436. Krauss, Rosalind 1982 Photography's Discursive Spaces: Landscape=View. Art Journal, 42(4): 311319.

Krautwurst, Udo 2002 The Joy of Looking. Early German Anthropology, Photography and Audience Formation. Visual Anthropology Review, 18(1-2): 55-79.

Lalvani, Suren 1990 Photography and the Industrialization of the Body. Journal of Communication Inquiry, 14: 86-105.

Langbehn, Volker M. 2010 German Colonialism, Visual Culture, and Modern Memory. New York and London: Taylor \& Francis.

Maxwell, Anne 2010 Picture Imperfect. Photography and Eugenics, 1870-1940. Eastbourne: Sussex Academic Press.

Mitchell, W. J. T. 1996 What do Pictures Really Want? October, 77: 71-82.

Olusoga, David, and Kasper W. Erichsen 2010 The Kaiser's Holocaust. Germany's Forgotten Genocide and the Roots of Nazism. London: Faber \& Faber.

Phillips, Sandra S., Mark Haworth-Booth, and Carol Squiers 1997 Police Pictures: The Photograph as Evidence. San Francisco: Chronicle Books. 2010 Exposed. Voyeurism, Surveillance and the Camera. London: Tate Publishers.

Pick, Daniel 1989 Faces of Degeneration. A European Disorder, ca. 1848-1918. Cambridge: Cambridge University Press.

Pierce, Steven, and Anupama Rao 2006 Discipline and the Other Body. Humanitarianism, Violence, and the Colonial Exception. In Discipline and the Other Body. Correction, Corporeality, Colonialism. Steven Pierce and Anupama Rao, eds. Pp. 1-35. Durham, NC, and London: Duke University Press.

Pinney, Christopher 2008 The Coming of Photography in India. London: British Library. 2011 Photography and Anthropology. London: Reaktion Books.

Pinney, Christopher, and Nicholas Peterson 2003 Photography's Other Histories. Durham, NC, and London: Duke University Press.

Poole, Deborah 1997 Vision, Race and Modernity: A Visual Economy of the Andean Image World. Princeton: Princeton University Press.

Rajchman, John 1988 Foucault's Art of Seeing. October, 44: 88-117.

Regener, Susanne 1999 Fotografische Erfassung. Zur Geschichte medialer Konstruktionen des Kriminellen. Munich: Wilhelm Fink Verlag.

Rizzo, Lorena 2007 The Elephant Shooting-Inconsistencies of Colonial Law and Indirect Rule in Kaoko (North-western Namibia) in the 1920s and 1930s. Journal of African History, 48(2): 245-266. 
2010 Gender and Colonialism. A History of Kaoko in North-western Namibia, 1870s-1950s. Basel: Basler Afrika Bibliographien.

Roberts, Russel 1997 Photography and Classification. In In Visible Light: Photography and Classification in Art, Science and the Everyday. Chrissie Iles and Russel Roberts, eds. Pp. 9-53. Oxford: Museum of Modern Art.

Rose, Gillian 2000 Practicing Photography: An Archive, a Study, Some Photographs and a Researcher. Journal of Historical Geography, 26(4): 555-571.

2001 Visual Methodologies, an Introduction to Researching with Visual Materials. London and Thousand Oaks: Sage Publications.

Rugoff, Ralph, Anthony Widler, and Peter Wollen 1997 Scene of the Crime. Los Angeles: UCLA=Armand Hammer Museum of Art and MIT Press.

Schwartz, Joan M. 2004 Review Essay. American Archivist, 67(1): 7.

Sekula, Allan 1988 The Body and the Archive. October, 39: 3-64.

Sontag, Susan 1979 On Photography. Harmondsworth: Penguin Books.

Tagg, John 1988 The Burden of Representation. Essays on Photographies and Histories. Minneapolis: University of Minnesota Press.

Tamony, Peter 19711851 Vigilante Daguerrotypes: Modern Mugging. Western Folklore, 30(2): 127-132.

Trachtenberg, Alan 1980 Classic Essays on Photography. New Haven: Leete's Island Books.

Trouillot, Michel R. 1997 Silencing the Past. Power and the Production of History. Boston: Beacon Press.

Van Onselen, Charles 2007 The Fox and the Flies. The Criminal Empire of the Whitechapel Murderer. London: Vintage Books.

Vivelo, Frank Robert 1995 Herero. In Encyclopedia of World Cultures, Volume IX, Africa and the Middle East. David Levinson, John Middleton, and Amal Rassam, eds. Pp. 115-118. Boston: G. K. Hall \& Co.

Wallace, Marion 2011 A History of Namibia. From the Beginning to 199o. London: Hurst. Webster, Christopher 2000 The Portrait Cabinet of Dr. Bleek: Anthropometric Photographs by Early Cape Photographers. Critical Arts, 14(1): 1-15.

Wride, Tim B., and James Ellroy 2004 Scenes of the Crime: Photographs from the Los Angeles Police Department Archive. New York: Harry N. Abrams.

Zimmerer, Jürgen 2001 Deutsche Herrschaft über Afrikaner. Staatlicher Machtanspruch und Wirklichkeit im kolonialen Namibia. Hamburg and Mü nster: Lit Verlag.

Zimudzi, Tapiwa B. 2004 African Women, Violent Crime and the Criminal Law in Colonial Zimbabwe. Journal of Southern African Studies, 30(3): 499-517. 